\title{
Coal fly ash: Linking immersion freezing behavior and physico-chemical particle properties
}

\author{
Sarah Grawe et. al \\ Correspondence to: Sarah Grawe (grawe@tropos.de)
}

\section{ALABAMA}

Several thousand single particle mass spectra were analyzed for each CFA sample. The chemical compounds contained in the quasi-monodisperse samples were investigated by calculating the signal average for every mass-to-charge ratio and by considering the relative abundance of mass-to-charge signals within the sample. Note that different ions can occur on one mass-to-charge ratio. The averaged mass spectra (see Fig. S1) must always be regarded in conjunction with the relative abundance, i.e., the information how many of the investigated particles contain a certain species (see Fig. S2). For determination of the relative abundance, only particle related signals should be considered. Therefore, signal thresholds were derived by averaging 1900 background spectra (without particles) to exclude signals which originate from, e.g., molecules evaporating from surfaces, vacuum grease, or remaining air molecules. Threshold values for anions $(21.6 \mathrm{mV} \pm 5.1 \mathrm{mV})$ and cations $(8.2 \mathrm{mV}$ $\pm 0.8 \mathrm{mV}$ ) were derived by averaging the means of the mass-to-charge ratios plus five times their standard deviation over all background spectra. In case the signal intensity at a certain mass-to-charge ratio was above (below) the threshold, the particle was classified as (not) containing this species. The averaged mass spectra include all signals regardless of whether the signals of the mass-to-charge ratios were above or below the mentioned thresholds.

Averaged mass spectra show that components frequently occurring in natural mineral dust are also typical constituents of dry-generated submicron CFA particles. This comprises species containing $\mathrm{Al}\left[{ }^{-43} \mathrm{AlO},{ }^{-59} \mathrm{AlO}_{2},{ }^{+27} \mathrm{Al}\right], \mathrm{Ca}\left[{ }^{+40} \mathrm{Ca},{ }^{+44} \mathrm{Ca}\right.$, $\left.{ }^{+56} \mathrm{CaO},{ }^{+104} \mathrm{CaSO}_{2}\right], \mathrm{K}\left[{ }^{+39} \mathrm{~K},{ }^{+41} \mathrm{~K}\right], \mathrm{Fe}\left[{ }^{+54} \mathrm{Fe},{ }^{+56} \mathrm{Fe}\right], \mathrm{Si}^{-60} \mathrm{SiO}_{2},{ }^{-76} \mathrm{SiO}_{3},{ }^{-88}(\mathrm{SiO})_{2},{ }^{-103} \mathrm{AlSiO}_{3},{ }^{-119} \mathrm{AlSiO}_{4}$, $\left.{ }^{-179} \mathrm{AlSi}_{2} \mathrm{O}_{6}\right], \mathrm{Na}\left[{ }^{+23} \mathrm{Na}\right]$, and $\mathrm{Mg}\left[{ }^{+24} \mathrm{Mg},{ }^{+25} \mathrm{Mg},{ }^{+26} \mathrm{Mg}\right.$. More than $80 \%$ of particles from all samples contain ${ }^{-16} \mathrm{O}$, ${ }^{+27} \mathrm{Al},{ }^{+40} \mathrm{Ca},{ }^{+44} \mathrm{Ca}$, and ${ }^{+56} \mathrm{CaO} / \mathrm{Fe} / \mathrm{Si} 2 / \mathrm{KOH}$. Besides, $\mathrm{SO}_{\mathrm{n}}$ and $\mathrm{PO}_{\mathrm{n}}$ are frequently found in the CFA particles. Single particle mass spectra with high signals of $(\mathrm{CaO})_{n},(\mathrm{CaO})_{n} \mathrm{H}$, and $\mathrm{Ca}(\mathrm{CaO})_{n}$ cluster series together with $\mathrm{SO}_{\mathrm{n}}$ may be related to $\mathrm{CaSO}_{4}$, as shown by Gallavardin et al. (2008).

It has been reported that especially submicron CFA particles often show an enrichment in trace elements (Davison et al., 1974; Kaakinen et al., 1975; Block and Dams, 1976; Gladney et al., 1976; Tan et al., 2002). This is also true for our samples as $\mathrm{Li}\left[{ }^{+6} \mathrm{Li},{ }^{+7} \mathrm{Li}\right], \mathrm{Ti}\left[{ }^{+46} \mathrm{Ti},{ }^{+47} \mathrm{Ti},{ }^{+48} \mathrm{Ti}\right], \mathrm{Co}\left[{ }^{+59} \mathrm{Co}\right], \mathrm{Zn}\left[{ }^{+64} \mathrm{Zn},{ }^{+66} \mathrm{Zn},{ }^{+68} \mathrm{Zn}\right], \mathrm{Sr}\left[{ }^{+86} \mathrm{Sr},{ }^{+87} \mathrm{Sr},{ }^{+88} \mathrm{Sr},{ }^{+104} \mathrm{SrO}\right], \mathrm{Ba}\left[{ }^{+136} \mathrm{Ba}\right.$,

$\left.25{ }^{+137} \mathrm{Ba},{ }^{+138} \mathrm{Ba},{ }^{+154} \mathrm{BaO}\right]$, and $\mathrm{Pb}\left[{ }^{+206} \mathrm{~Pb},{ }^{+207} \mathrm{~Pb},{ }^{+208} \mathrm{~Pb}\right]$ were detected. Especially $\mathrm{Ti}, \mathrm{Sr}$ and $\mathrm{Ba}$ frequently frequently occur in the sampled CFA particles. At least $50 \%$ of the CFA particles contained ${ }^{+48} \mathrm{Ti},{ }^{+88} \mathrm{Sr}$ and ${ }^{+138} \mathrm{Ba}$, making them to 
potential markers for the detection of unprocessed atmospheric CFA particles. However, Gallavardin et al. (2008) showed that these elements are components of some mineral dust types such as illite, too. $\mathrm{Pb}\left[{ }^{+206} \mathrm{~Pb},{ }^{+207} \mathrm{~Pb},{ }^{+208} \mathrm{~Pb}\right]$ is present in $\sim 20$ $\%$ of CFA1 particles and $\sim 10 \%$ of CFA2 particles. In CFA3 and CFA4 almost no particles contained Pb signals above the threshold, and hence it cannot be used as a marker for CFA.

5 In order to find a systematic difference in the chemical composition of dry- and wet-generated CFA particles, the signal ratio wet/dry was determined (see Fig. S3). In the following, we only focus on features that are characteristic of all CFA samples. A significant enhancement of signal intensity up to several hundreds of percent can be seen for mass-to-charge ratios [ +57 , +113], hinting at hydration of $\mathrm{CaO}$. To explain the observed changes in signal intensity, we suggest the reactions R1, R2, R5, and R6, where R1 and R2 represent the hydration reaction, and R5 and R6 represent a possible molecular fragmentation after vaporization and ionization in ALABAMA. An increase was also found for mass-to-charge ratios [+105, +155], indicating the hydration of $\mathrm{SrO}$ and $\mathrm{BaO}$ (R3, R4 and R7, R8). Furthermore, a decrease of S-containing substances was registered: ${ }^{-32} \mathrm{~S}$, ${ }^{-48} \mathrm{SO},{ }^{-64} \mathrm{SO}_{2},{ }^{-80} \mathrm{SO}_{3},{ }^{-81} \mathrm{HSO}_{3},{ }^{-96} \mathrm{SO}_{4}$, and ${ }^{-97} \mathrm{HSO}_{4}$ all appear to be reduced in wet-generated particles, which could be an indication for $\mathrm{S}$ being dissolved from $300 \mathrm{~nm}$ particles.

${ }^{56} \mathrm{CaO}+{ }^{18} \mathrm{H}_{2} \mathrm{O} \rightarrow{ }^{74} \mathrm{Ca}(\mathrm{OH})_{2}$

${ }^{96} \mathrm{Ca}_{2} \mathrm{O}+{ }^{18} \mathrm{H}_{2} \mathrm{O} \rightarrow{ }^{114} \mathrm{Ca}_{2}(\mathrm{OH})_{2}$

${ }^{104} \mathrm{SrO}+{ }^{18} \mathrm{H}_{2} \mathrm{O} \rightarrow{ }^{122} \mathrm{Sr}(\mathrm{OH})_{2}$

${ }^{154} \mathrm{BaO}+{ }^{18} \mathrm{H}_{2} \mathrm{O} \rightarrow{ }^{172} \mathrm{Ba}(\mathrm{OH})_{2}$

${ }^{74} \mathrm{Ca}(\mathrm{OH})_{2} \rightarrow{ }^{+57} \mathrm{CaOH}+{ }^{-17} \mathrm{OH}$

${ }^{114} \mathrm{Ca}_{2}(\mathrm{OH})_{2} \rightarrow{ }^{+113} \mathrm{Ca}_{2} \mathrm{O}_{2} \mathrm{H}+{ }^{-1} \mathrm{H}$

${ }^{122} \mathrm{Sr}(\mathrm{OH})_{2} \rightarrow{ }^{+105} \mathrm{SrOH}+{ }^{-17} \mathrm{OH}$

${ }^{172} \mathrm{Ba}(\mathrm{OH})_{2} \rightarrow{ }^{+155} \mathrm{BaOH}+{ }^{-17} \mathrm{OH}$

Averaged mass spectra of dry-dispersed CFA particles were used for identifying species that contribute to or do not seem to have an impact on the observed immersion freezing behavior. This was done by searching the mass spectra for species whose signal intensity correlates or anti-correlates with $f_{\text {ice }}$ from LACIS measurements of the CFA samples (see Fig. S4). In case of correlation (see Fig. S4 a), only those peaks are shown for which the signal intensity is highest for CFA1 and lowest for CFA3. In case of anti-correlation (see Fig. S4 b), only those peaks are shown for which the signal intensity is highest for CFA3 and 
lowest for CFA1. CFA2 and CFA4 were not considered separately as they have a very similar immersion freezing behavior. The above mentioned threshold was taken into account by just considering species, which were present in at least $10 \%$ of CFA1 (correlation) or CFA3 (anti-correlation) particles.

Certain groups of compounds appear more often than others in relation to the total number of correlating/anti-correlating 5 species. $\mathrm{Ca}\left[{ }^{+40} \mathrm{Ca},{ }^{+42} \mathrm{Ca},{ }^{+44} \mathrm{Ca},{ }^{+96} \mathrm{Ca}_{2} \mathrm{O},{ }^{+104} \mathrm{CaSO}_{2} / \mathrm{SrO},{ }^{+112}(\mathrm{CaO})_{2}\right]-$ and $\mathrm{S}\left[{ }^{-32} \mathrm{~S},{ }^{-48} \mathrm{SO}\right]$-containing species have highest signal intensities for CFA1 and lowest for CFA3. Also, correlation was found for $\mathrm{Pb}\left[{ }^{+206} \mathrm{~Pb},{ }^{+207} \mathrm{~Pb},{ }^{+208} \mathrm{~Pb}\right]$. Anticorrelation was found for many compounds amongst which $\mathrm{Si}^{-60} \mathrm{SiO}_{2},{ }^{-76} \mathrm{SiO}_{3},{ }^{-77} \mathrm{HSiO}_{3},{ }^{-99} \mathrm{NaSiO}_{3},{ }^{-119} \mathrm{AlSiO}_{4},{ }^{+28} \mathrm{Si}$, $\left.{ }^{+56} \mathrm{Si}_{2}\right]$ - and $\mathrm{Al}\left[{ }^{-43} \mathrm{AlO},{ }^{-119} \mathrm{AlSiO}_{4},{ }^{+27} \mathrm{Al}\right]$-containing species occur frequently. In summary, the immersion freezing behavior of our CFA samples seems to be influenced by species containing $\mathrm{Ca}$ and $\mathrm{S}$, and possibly by trace elements. Si and $\mathrm{Al}$ 10 do not appear to contribute to the differences in immersion freezing efficiency that were observed between CFA samples. 

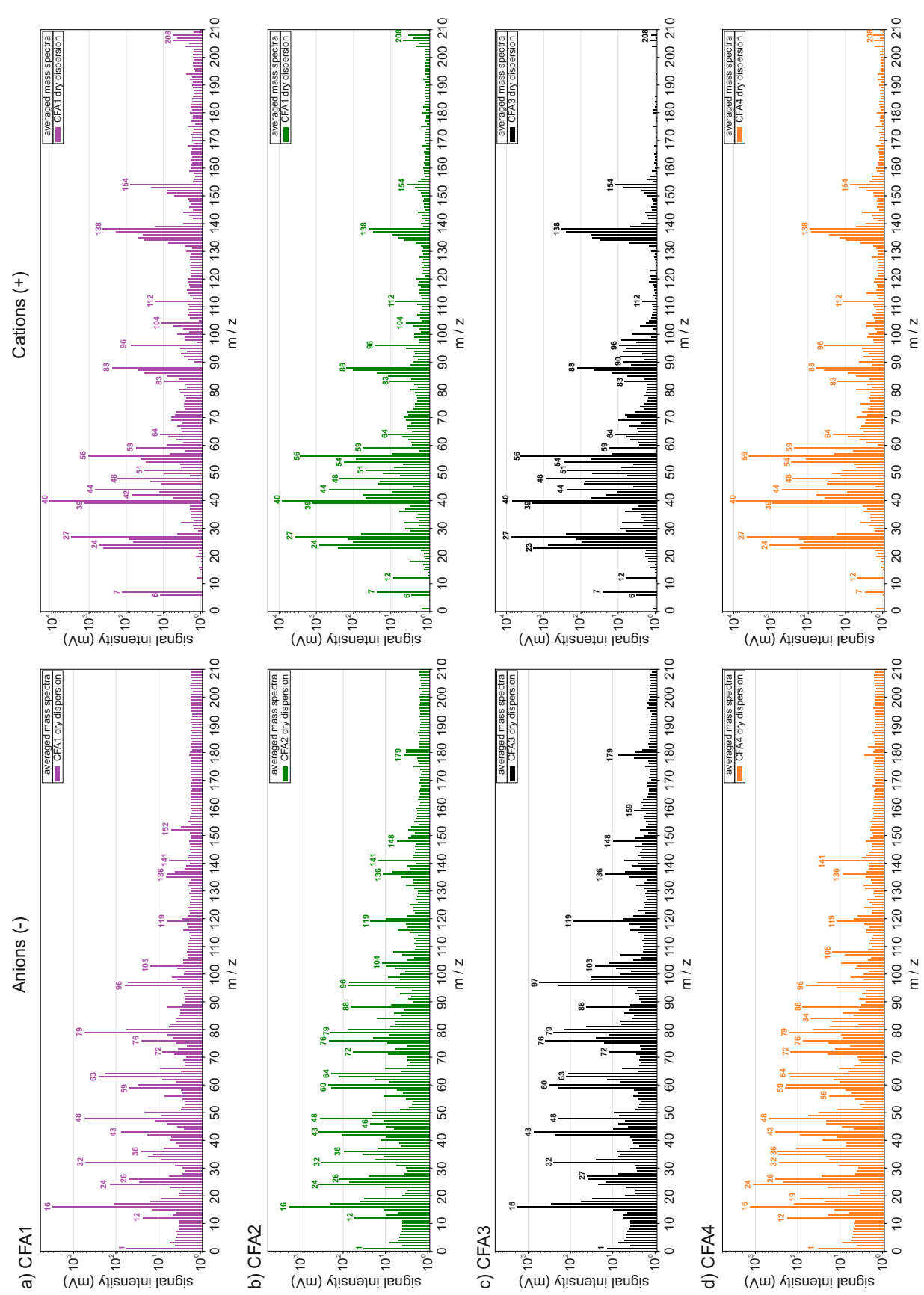

Figure S1. Averaged mass spectra for $300 \mathrm{~nm}$ dry-generated CFA particles. Common mass-to-charge ratios from left to right: [-16] O, [-32] $\mathrm{S}$, [-43] $\mathrm{AlO},[-48] \mathrm{SO},[-59] \mathrm{AlO}_{2},[-60] \mathrm{SiO}_{2},[-63] \mathrm{PO}_{2}$, [-64] $\mathrm{SO}_{2}$, [-76] $\mathrm{SiO}_{3},[-79] \mathrm{PO}_{3}$, [-80] $\mathrm{SO}_{3},[-88](\mathrm{SiO})_{2},[-96] \mathrm{SO}_{4},[-103]$ $\mathrm{AlSiO}_{3},[-119] \mathrm{AlSiO}_{4},[-179] \mathrm{AlSi}_{2} \mathrm{O}_{6},[+6,+7] \mathrm{Li},[+23] \mathrm{Na},[+24,+25,+26] \mathrm{Mg},[+27] \mathrm{Al},[+39,+41] \mathrm{K},[+40,+44] \mathrm{Ca},[+46,+47,+48]$ $\mathrm{Ti},[+54] \mathrm{Fe},[+56] \mathrm{CaO} / \mathrm{Fe} / \mathrm{Si} 2 / \mathrm{KOH},[+59] \mathrm{Co},[+64,+68] \mathrm{Zn},[+86,+87,+88] \mathrm{Sr},[+104] \mathrm{SrO} / \mathrm{CaSO}_{2},[+136,+137,+138] \mathrm{Ba},[+154]$ $\mathrm{BaO},[+206,+207,+208] \mathrm{Pb}$. 

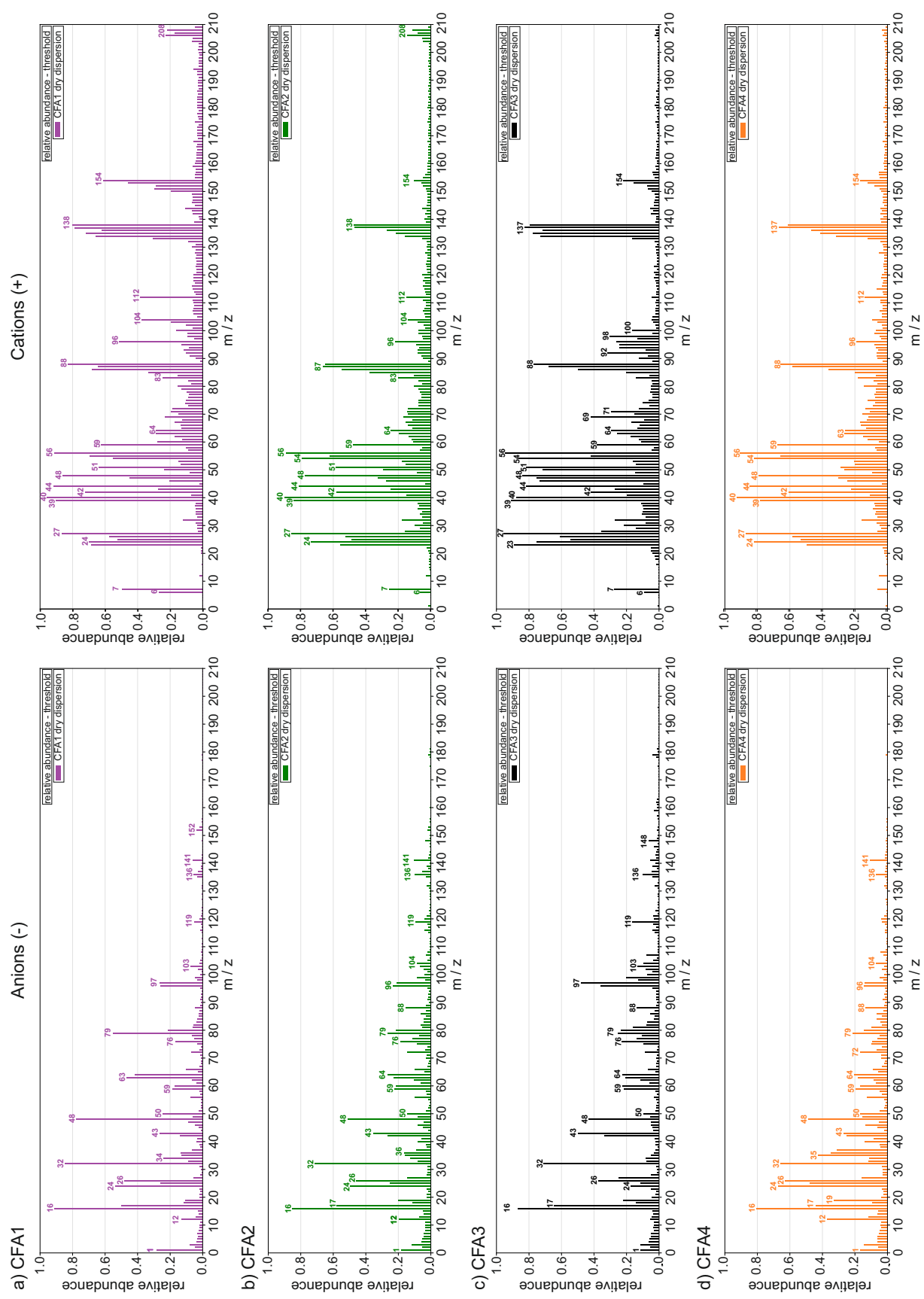

Figure S2. Relative abundance of species in $300 \mathrm{~nm}$ dry-generated CFA particles. Background signals were determined and used as a threshold to decide whether a particle contained/did not contain a certain species. Common mass-to-charge ratios from left to right: [-16] $\mathrm{O},[-32] \mathrm{S},[-43] \mathrm{AlO},[-48] \mathrm{SO},[-59] \mathrm{AlO}_{2},[-60] \mathrm{SiO}_{2},[-63] \mathrm{PO}_{2},[-64] \mathrm{SO}_{2},[-76] \mathrm{SiO}_{3},[-79] \mathrm{PO}_{3},[-80] \mathrm{SO}_{3},[-88](\mathrm{SiO})_{2},[-96] \mathrm{SO}_{4}$, [-103] $\mathrm{AlSiO}_{3},[-119] \mathrm{AlSiO}_{4},[+6,+7] \mathrm{Li},[+23] \mathrm{Na},[+24,+25,+26] \mathrm{Mg},[+27] \mathrm{Al},[+39] \mathrm{K},[+40,+42,+44] \mathrm{Ca},[+46,+47,+48] \mathrm{Ti},[+54]$ $\mathrm{Fe},[+56] \mathrm{CaO} / \mathrm{Fe} / \mathrm{Si} 2 / \mathrm{KOH},[+59] \mathrm{Co},[+64] \mathrm{Zn},[+86,+87,+88] \mathrm{Sr},[+104] \mathrm{SrO} / \mathrm{CaSO}_{2},[+136,+137,+138] \mathrm{Ba},[+154] \mathrm{BaO},[+206,+207$, $+208] \mathrm{Pb}$. 


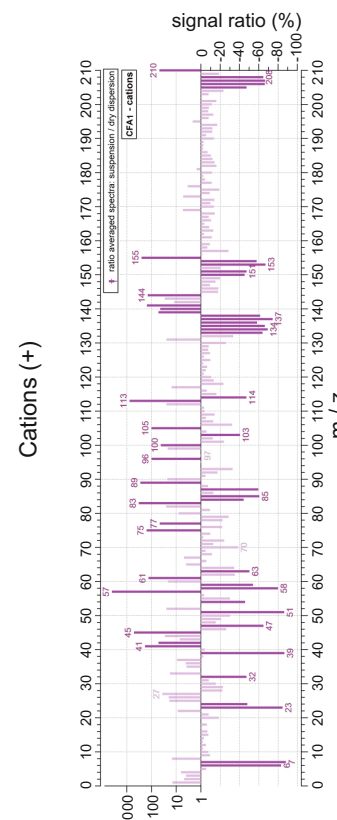

(\%) o!̣ed jeubịs

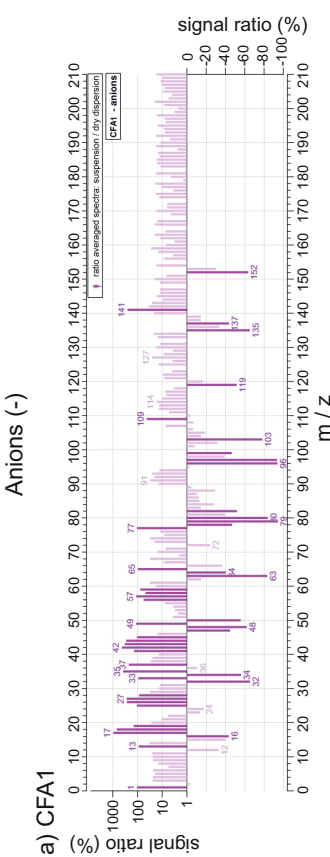

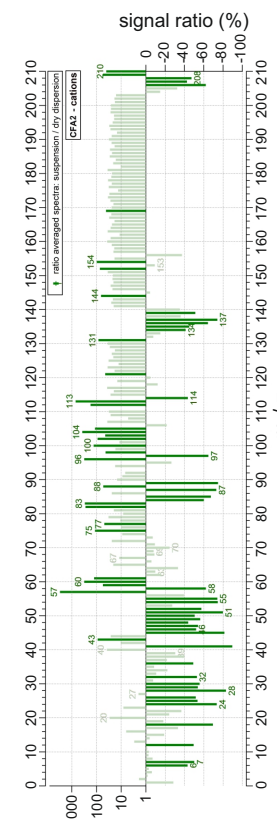

(\%) o!̣ed jeub!̣

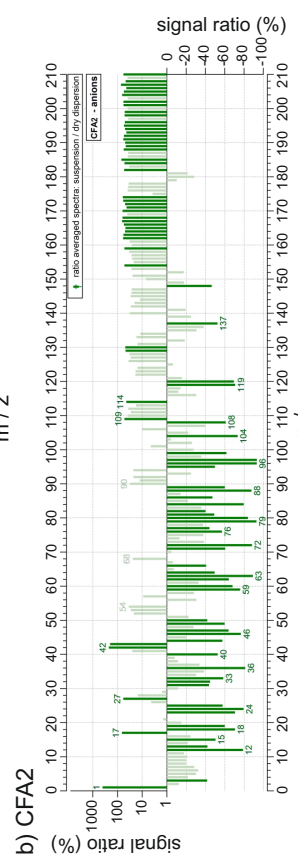

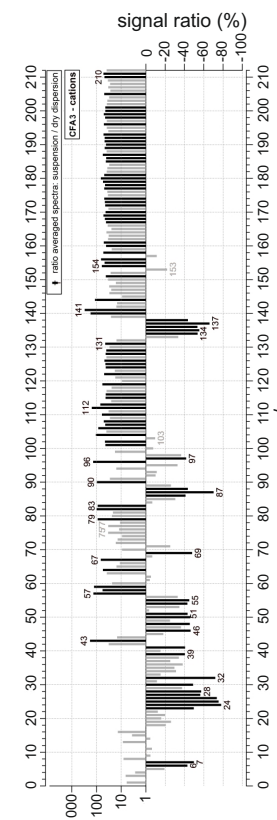

(\%) ọ̣ed ןeu6!̣s

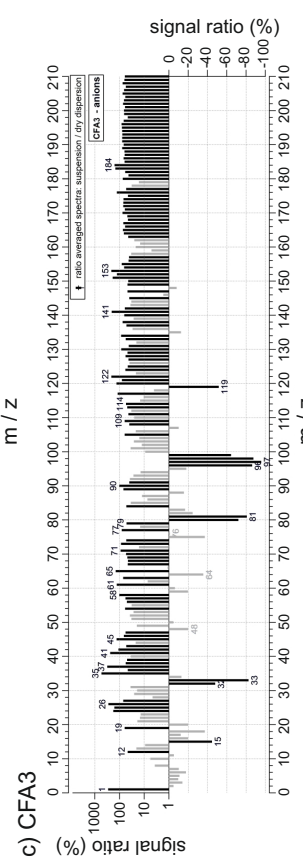

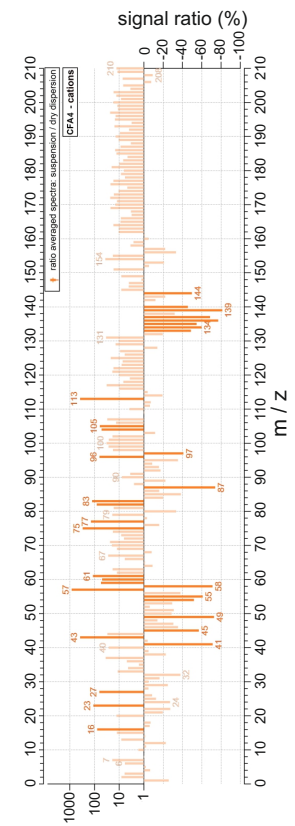

(\%) o!̣ed jeub!̣

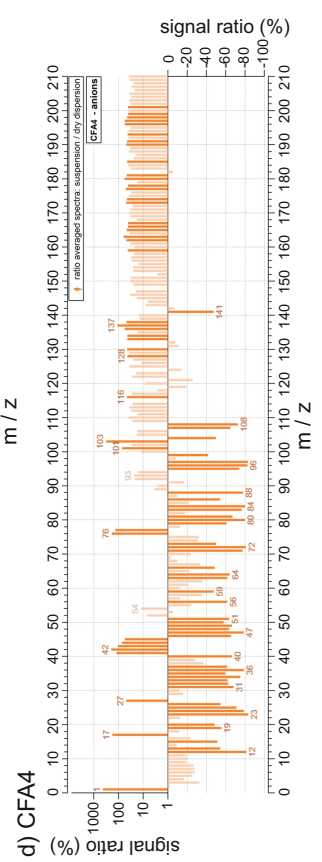

Figure S3. Signal ratio of $300 \mathrm{~nm}$ wet- vs. dry-dispersed CFA particles. Positive bars represent an increase in signal intensity for wetgenerated particles in comparison to dry-generated particles. Stronger colors indicate species for which the signal intensity has changed by more than $40 \%$. Common mass-to-charge ratios from left to right: [-32] S, [-48] SO, [-64] $\mathrm{SO}_{2}$, [-80] $\mathrm{SO}_{3}$, [-81] $\mathrm{HSO}_{3}$, [-96] $\mathrm{SO}_{4}$, [-97] $\mathrm{HSO}_{4},[+57] \mathrm{CaOH},[+105] \mathrm{SrOH},[+113] \mathrm{Ca}_{2} \mathrm{O}_{2} \mathrm{H},[+155] \mathrm{BaOH}$. 

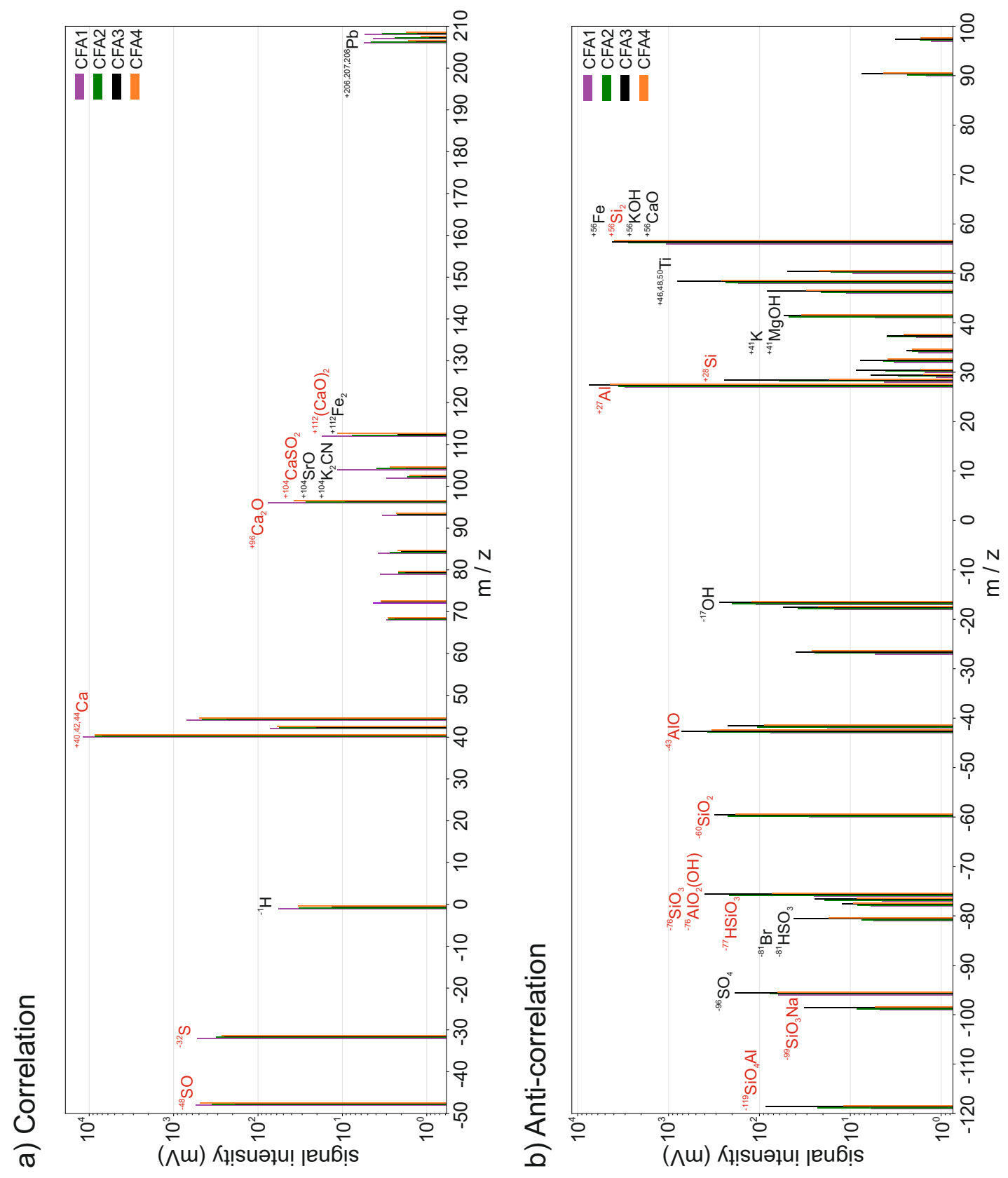

Figure S4. Averaged mass spectra. Shown are only those species for which the signal intensity a) correlates (CFA1 $>$ CFA2,CFA4 $>$ CFA3) or b) anti-correlates (CFA3>CFA2,CFA4>CFA1) with $f_{\text {ice }}$ of dry-generated CFA. Red labels indicate Ca- and S-containing species in case of correlation and $\mathrm{Si}$ - and Al-containing species in case of anti-correlation. Species with signal intensities $<10$ were not considered, except for mass-to-charge ratios $[+206,+207,+208]$ indicating a correlation with $\mathrm{Pb}$. 


\section{ESEM/EDX}

Fig. S5 shows the ESEM images of dry- and wet-generated quasi-monodisperse CFA particles. Spherical particles, often described as the main particle type in CFA in literature (e.g., Davison et al., 1974; Ramsden and Shibaoka, 1982; Flanders, 1999; Zhang et al., 2011), were rarely detected in the dry-generated samples. Spherical shapes are thought to originate from

5 combustion of organic substances and melting of mineral inclusions in the coal, leading to the formation of spherical ash droplets (Damle et al., 1982; Flagan and Seinfeld, 1988). The spherical shape is often retained as the particles cool and solidify, however, particles can also be deformed. Seames (2003) reported CFA particles in the size range between 0.1 and 1 $\mu \mathrm{m}$ with irregular shapes, comparable to the morphology shown in Fig. S5 and argued that this deviation from the sphere could be the result of particle inflation, cracking, or shedding due to expanding gases, partial melting, and/or agglomeration. The latter is a probable mechanism in the case of CFA1, where many particles consisting of aggregates of small spherules can be seen. Differences in morphology between the different CFA samples can be explained by differences in coal composition and combustion conditions (Zhang et al., 2006). In general, the wet-generated CFA particles feature a more uniform and compact shape than the dry-generated ones, maybe because irregularities are covered by a layer of dissolved and redistributed material during suspension and subsequent atomization (Herich et al., 2009). An exception are wet-generated CFA1 particles, which, in addition to spheroidal particles, occur as needle shaped crystals (see Appendix B).

The results of the EDX chemical composition analysis are summarized in Table S1. EDX was performed for each sample for both, dry- and wet-generated particles. Elements that were detected in all samples, either from dry or wet particle generation are $\mathrm{O}, \mathrm{Ca}$, and $\mathrm{Si}$, which is in agreement with the ALABAMA mass spectra. However, characteristic trace elements ( $\mathrm{Ti}, \mathrm{Co}$, $\mathrm{V}, \mathrm{Ba}, \mathrm{Sr}, \mathrm{Zn}$, and $\mathrm{Pb}$ ), that are present in the CFA samples according to ALABAMA, were not detected by EDX. Differences between dry- and wet-generated particles were identified and, for the most part, agree with the mass spectra. However, EDX results should be treated with caution from a statistical point of view: Due to the time-consuming analysis and the, in parts, non-ideal loading of the substrates, 20 particles were characterized in each case. Hence, a more detailed comparison between samples, particle generation methods, and to the ALABAMA mass spectra cannot be provided. 

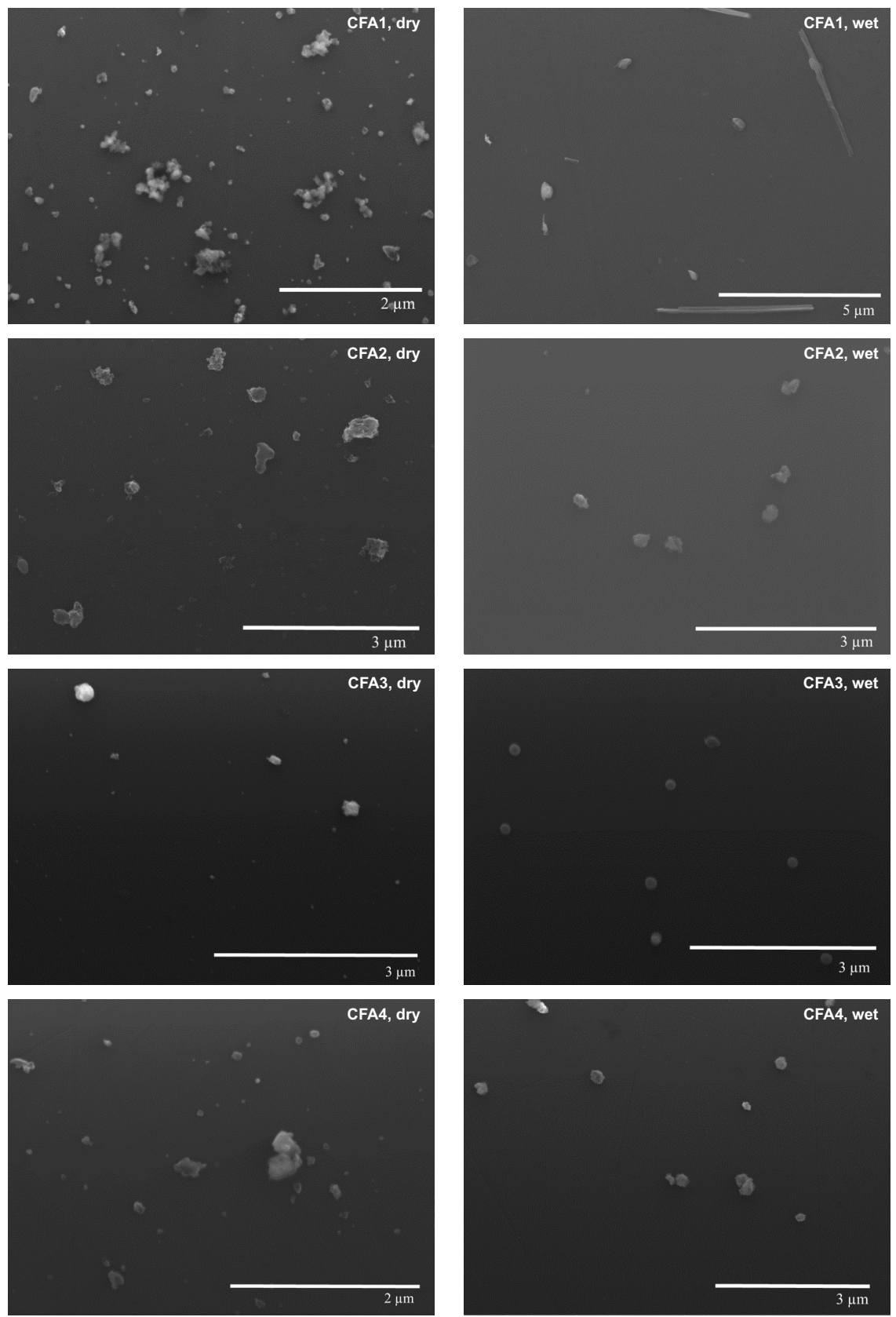

Figure S5. ESEM images of quasi-monodisperse $(300 \mathrm{~nm})$ CFA particles sampled onto B substrates with the MINI impactor. Left: Dry particle generation, right: wet particle generation. Note the different magnification. 
Table S1. Chemical composition of CFA particles from dry and wet particle generation as determined by EDX measurements. The number of investigated particles is given in parentheses. Elements in parentheses have only been detected in some of the particles.

\begin{tabular}{cllc}
\hline CFA sample & Dry particle generation & Wet particle generation & Difference wet/dry \\
\hline 1 & $\mathrm{O}, \mathrm{Ca}, \mathrm{Si}, \mathrm{S}(16)$ & $\mathrm{O}, \mathrm{Ca}, \mathrm{Al},(\mathrm{Fe}, \mathrm{Si})(15)$ & $-\mathrm{S}$ \\
& $\mathrm{Si}, \mathrm{O}(10)$ & $\mathrm{O}, \mathrm{Al},(\mathrm{Fe}, \mathrm{Si})(12)$ & $-\mathrm{Al}$ \\
\hline 2 & $\mathrm{O}, \mathrm{Fe}, \mathrm{Al}, \mathrm{Si}, \mathrm{S}, \mathrm{Ca}(9)$ & $\mathrm{O}, \mathrm{Ca}, \mathrm{Al}, \mathrm{Si}, \mathrm{S}(16)$ & \\
& $\mathrm{O}, \mathrm{Fe}, \mathrm{Al}, \mathrm{Si}, \mathrm{S}, \mathrm{Ca}, \mathrm{Mg}(7)$ & $\mathrm{O}, \mathrm{Ca}, \mathrm{Al}, \mathrm{Si}, \mathrm{S}, \mathrm{Fe}(3)$ & \\
& $\mathrm{O}, \mathrm{Si}, \mathrm{Ca}, \mathrm{Fe}(1)$ & $\mathrm{O}, \mathrm{Si}, \mathrm{Ca}(1)$ & \\
\hline \multirow{2}{*}{3} & $\mathrm{Si}, \mathrm{O}, \mathrm{Al}, \mathrm{Fe}, \mathrm{Ca},(\mathrm{Mg}, \mathrm{S})(9)$ & $\mathrm{Si}, \mathrm{O}, \mathrm{Al}, \mathrm{Fe}, \mathrm{Ca},(\mathrm{Mg}, \mathrm{S}, \mathrm{K})(5)$ & \\
& $\mathrm{Si}, \mathrm{O}(3)$ & $\mathrm{Si}, \mathrm{O},(\mathrm{Al}, \mathrm{Fe})(19)$ & $-\mathrm{C}$ \\
& $\mathrm{O}, \mathrm{S},(\mathrm{Al}, \mathrm{Fe}, \mathrm{Si})(3)$ & $\mathrm{O}, \mathrm{Ca}, \mathrm{Si}, \mathrm{S},(\mathrm{Fe}, \mathrm{Mg})(3)$ & \\
$\mathrm{O}, \mathrm{Ca}, \mathrm{Si}(1)$ & & \\
& $\mathrm{O}, \mathrm{Ca}(1)$ & & \\
\hline \multirow{2}{*}{4} & $\mathrm{Si}, \mathrm{O}(5)$ & $\mathrm{Si}, \mathrm{O}(11)$ \\
& $\mathrm{O}, \mathrm{C}, \mathrm{Si}, \mathrm{Ca}, \mathrm{Al},(\mathrm{Fe}, \mathrm{S}, \mathrm{Mg})(11)$ & $\mathrm{O}, \mathrm{Ca}, \mathrm{Si}, \mathrm{Al}, \mathrm{S},(\mathrm{Fe})(8)$ & \\
$\mathrm{Si}, \mathrm{O}, \mathrm{Al}(5)$ & $\mathrm{O}, \mathrm{Si},(\mathrm{Al}, \mathrm{Fe})(2)$ & \\
$\mathrm{C}, \mathrm{O}(2)$ & & \\
\hline
\end{tabular}




\section{XRD}

XRD patterns (see Fig. S6 to S9) were measured for the original samples and for the samples after being suspended in water which then was evaporated. This was done to identify major crystalline phases and processes taking place during the interaction of CFA with water. Note that this is a bulk investigation, i.e., a direct connection may not be drawn between XRD and the

5 LACIS, ALABAMA, and EDX results. Amounts of the identified phases are given in each plot but must be treated cautiously, as the CFA powder is quite inhomogeneous and only $\sim 0.5 \mathrm{~g}$ were used for an XRD measurement.

Quartz $\left(\mathrm{SiO}_{2}\right)$ is the major crystalline phase in all of the samples, either dry or after suspension. Anhydrite $\left(\mathrm{CaSO}_{4}\right)$ and lime $(\mathrm{CaO})$ occur in all of the dry samples, however, prominent peaks can only be seen for CFA1 (Fig. S6). Minor crystalline phases in the dry samples include mullite $\left(\mathrm{Al}_{6} \mathrm{Si}_{2} \mathrm{O}_{13}\right)$, gehlenite $\left(\mathrm{Ca}_{2} \mathrm{Al}\left[\mathrm{AlSiO} \mathrm{O}_{7}\right]\right)$, hematite $\left(\mathrm{Fe}_{2} \mathrm{O}_{3}\right)$, magnetite $\left(\mathrm{Fe}^{2+} / \mathrm{Fe}_{2}^{3+} \mathrm{O}_{4}\right)$, periclase $(\mathrm{MgO})$, rutile $\left(\mathrm{TiO}_{2}\right)$, anatase $\left(\mathrm{TiO}_{2}\right)$, and tricalcium-aluminate $\left(3 \mathrm{CaO} \cdot \mathrm{Al}_{2} \mathrm{O}_{3}\right)$, all of which have been identified previously in CFA samples of different geographical origin (e.g., McCarthy et al., 1984; Querol et al., 1996; Nathan et al., 1999; Shoumkova et al., 2005; Ward and French, 2006; Liang et al., 2010; Nyambura et al., 2011).

Distinct changes in the XRD pattern of dry particles and particles that have been suspended in water can be seen for CFA1. Here, the hydration of anhydrite $\left(\mathrm{CaSO}_{4}\right)$ to gypsum $\left(\mathrm{CaSO}_{4} \cdot 2 \mathrm{H}_{2} \mathrm{O}\right.$, see $\mathrm{R} 1$ of the main text) can be observed. This is a process which is also relevant for submicron CFA particles, as those are likely to be coated with anhydrite (Enders, 1996). Also, the patterns indicate that lime $(\mathrm{CaO})$ is converted into calcite $\left(\mathrm{CaCO}_{3}\right)$ via hydration and carbonation (see $\mathrm{R} 2$ and $\mathrm{R} 3$ of the main text). Only minor changes between dry bulk and bulk after suspension can be seen for the other CFA samples, probably because they contain much less anhydrite and lime than CFA1 (see Sec. S4). The decrease of the magnetite fraction in suspension particles of CFA 2 and CFA3 in comparison to the dry bulk could be due to the suspension preparation routine. Ferromagnetic magnetite particles stick to the magnetic agitator while stirring. When removing the agitator from the suspension, those particles are depleted. However, we do not expect the removal of magnetic material from the CFA suspensions to cause the observed decrease in immersion freezing efficiency because a decrease was also observed for CFA suspensions which were not in contact with the magnetic agitator (see Fig. 5 of the main text).

It has been argued previously that the amorphous, i.e., non-crystalline, fraction may play an important role for the immersion freezing behavior of CFA particles (Umo et al., 2015). Even though the amorphous fraction was not quantitatively determined here, the broad "hump", which occurrs in the region up to $40^{\circ}$ and is most prominent in the CFA3 pattern (Fig. S8), indicates that this sample contains the highest amount of amorphous material in bulk. This is in accordance with findings by Ward and French (2006) who investigated the amorphous fraction of different CFA samples and showed that CFA from black coal combustion contains more amorphous material than CFA from brown coal combustion. Matsunaga et al. (2002) describe an increase of the amorphous fraction towards smaller particle sizes due to the fast cooling rates of small particles, i.e., CFA3 likely contains most amorphous material in $300 \mathrm{~nm}$ particles. From this, we can conclude that amorphous material in CFA does not seem to have a promoting effect on the immersion freezing efficiency, as CFA3 was the least efficient of the four dry-dispersed samples. 
a)

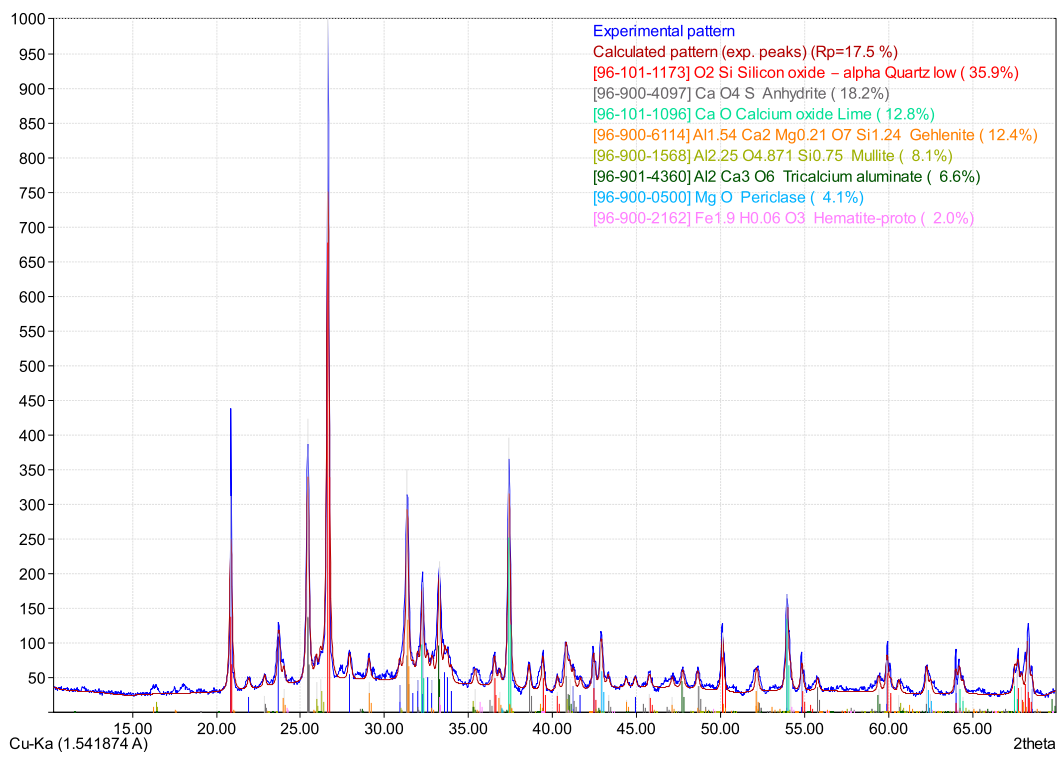

b)

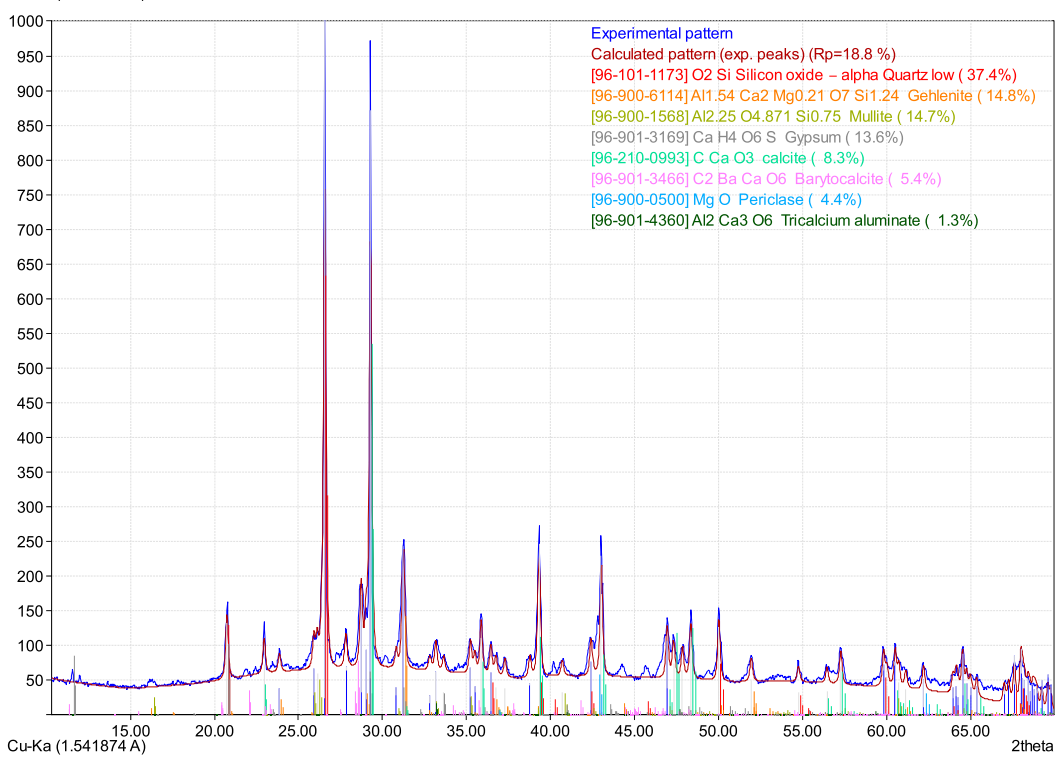

Figure S6. XRD patterns of a) dry bulk CFA1 and b) CFA1 after suspension and evaporation. 
a)

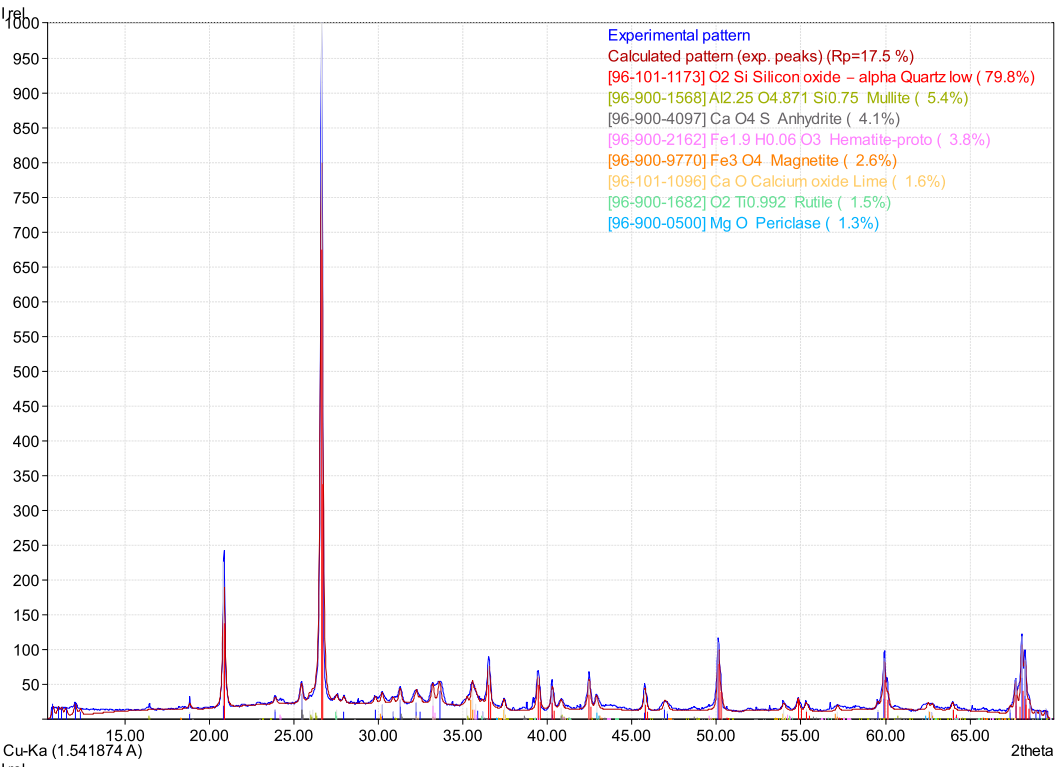

b)

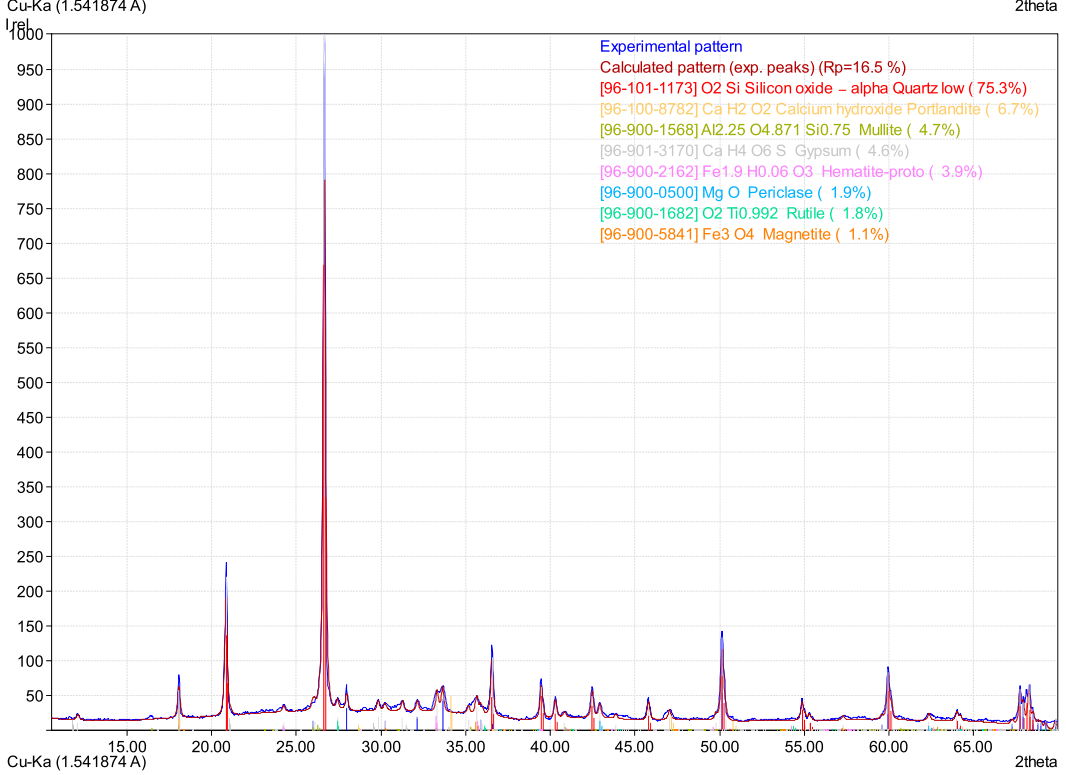

Figure S7. XRD patterns of a) dry bulk CFA2 and b) CFA2 after suspension and evaporation. 
a)

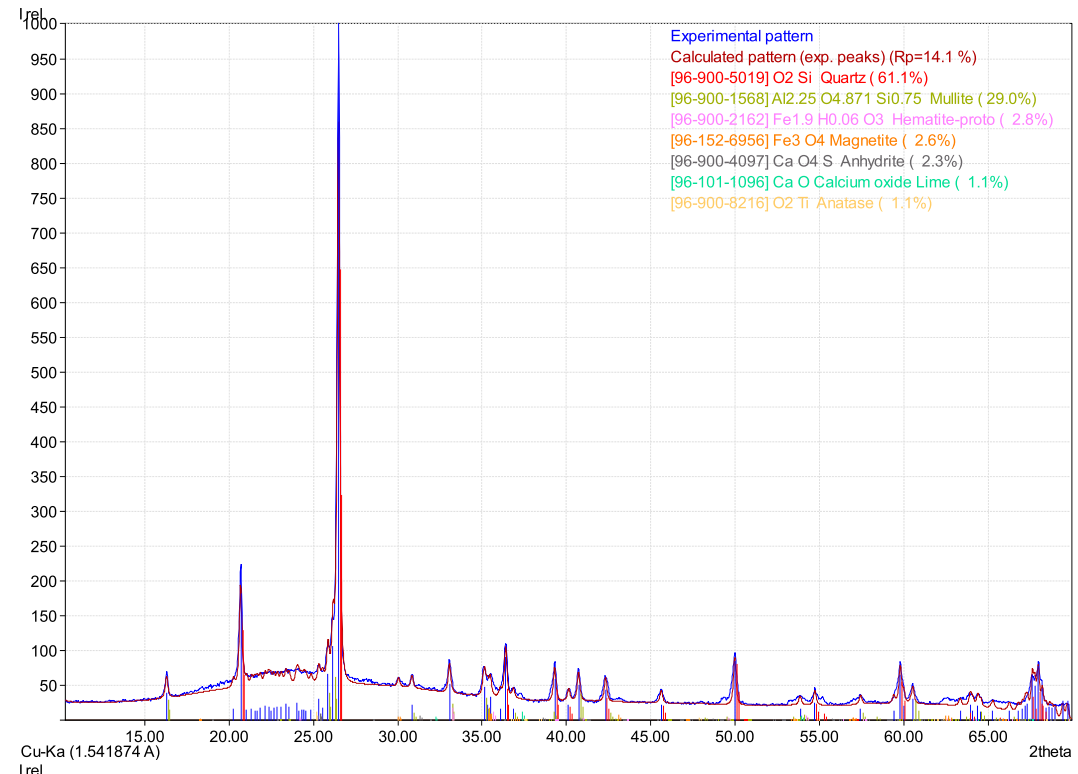

b)

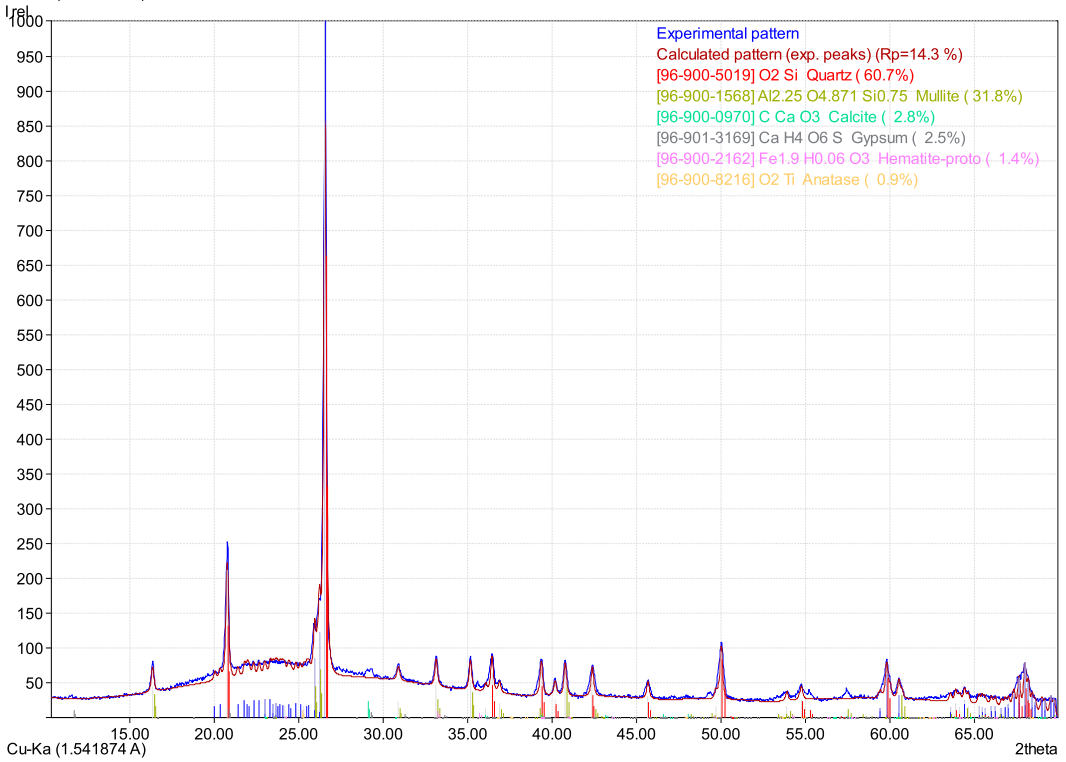

Figure S8. XRD patterns of a) dry bulk CFA3 and b) CFA3 after suspension and evaporation. 
a)

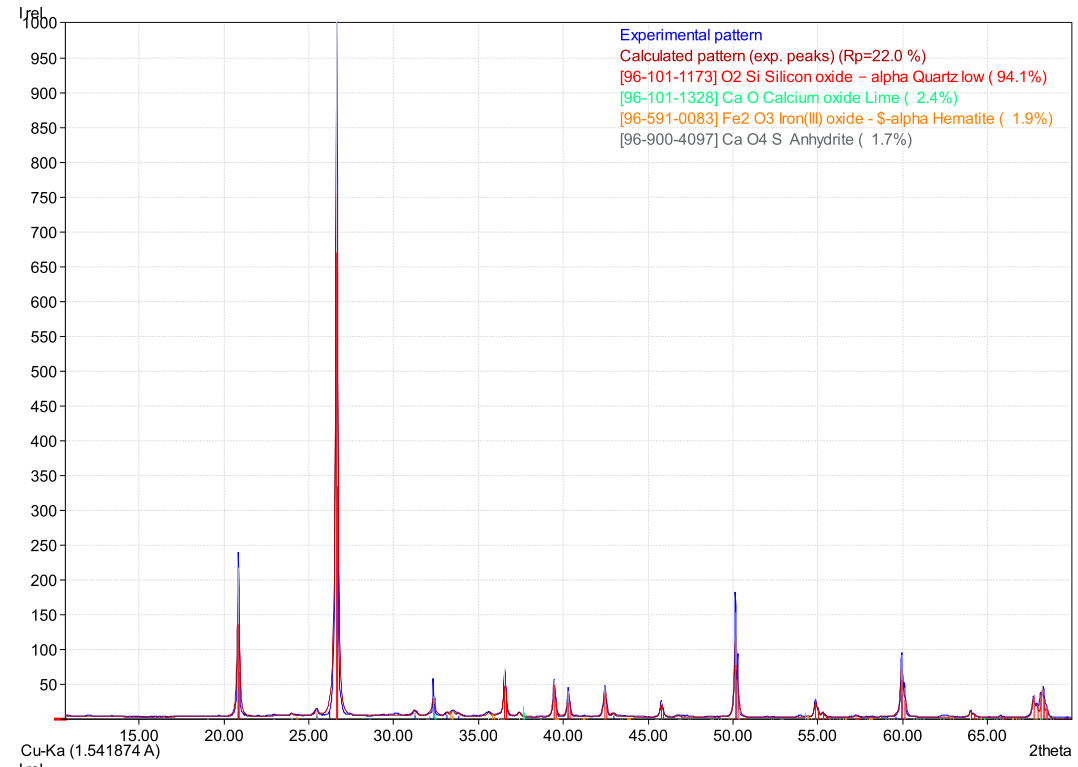

b)

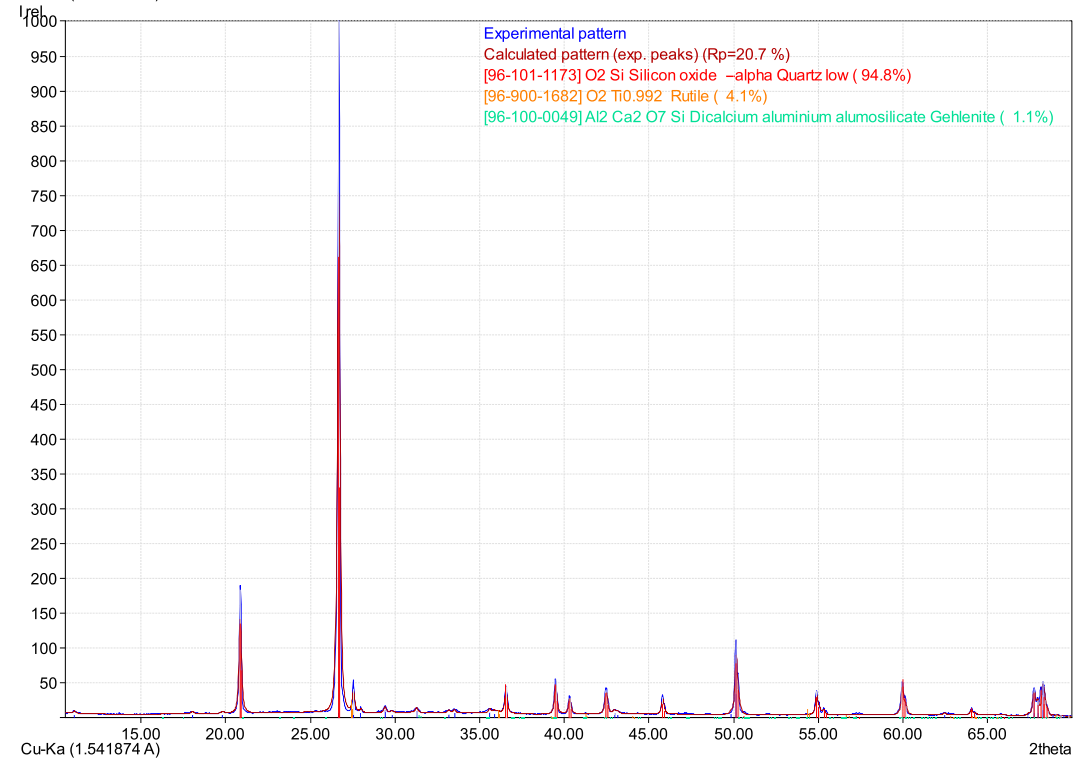

Figure S9. XRD patterns of a) dry bulk CFA4 and b) CFA4 after suspension and evaporation. 


\section{Bulk chemical composition analysis}

It is known that the chemical composition of CFA is dependent on particle size (e.g., Davison et al., 1974). Consequently, the bulk chemical composition is of limited value for identifying species influencing the immerison freezing behavior of $300 \mathrm{~nm}$ particles. However, the results can be used to classify the CFA samples according to the American Society for Testing Materials

5 (ASTM, standard C618, 2015). Traditionally, this classification is used to estimate which and how much CFA should be added to cement, because different classes of CFA have different effects on cement hardening and durability (Canpolat et al., 2004).

CFA is defined as class $\mathrm{F}$ when the combined content of $\mathrm{SiO}_{2}, \mathrm{Al}_{2} \mathrm{O}_{3}$, and $\mathrm{Fe}_{2} \mathrm{O}_{3}$ exceeds $70 \mathrm{wt} \%$. CFA is of class $\mathrm{C}$ when the combined content of $\mathrm{SiO}_{2}, \mathrm{Al}_{2} \mathrm{O}_{3}$, and $\mathrm{Fe}_{2} \mathrm{O}_{3}$ is between 50 and $70 \mathrm{wt} \%$. Class C CFA typically has a CaO content $\geq 20 \%$ causing cementitious (self-hardening when reacted with water) properties. Class F, with a typical $\mathrm{CaO}$ content of 1 to $12 \mathrm{wt} \%$, is 10 of pozzolanic nature (self-hardening when reacted with water and portlandite; Ahmaruzzaman, 2010). The combined contents of $\mathrm{SiO}_{2}, \mathrm{Al}_{2} \mathrm{O}_{3}$, and $\mathrm{Fe}_{2} \mathrm{O}_{3}$ of CFA1, CFA2, CFA3, and CFA4 are $51 \pm 8,84 \pm 13,85 \pm 14$, and $67 \pm 10 \mathrm{wt} \%$, respectively. The $\mathrm{CaO}$ contents of CFA1, CFA2, CFA3, and CFA4 are $26 \pm 4,12 \pm 2,2 \pm 0.4$, and $6 \pm 1 \mathrm{wt} \%$, respectively. Consequently, CFA 1 is of class $\mathrm{C}$ and CFA2, CFA3, and CFA4 are of class F, within measurement uncertainty. 

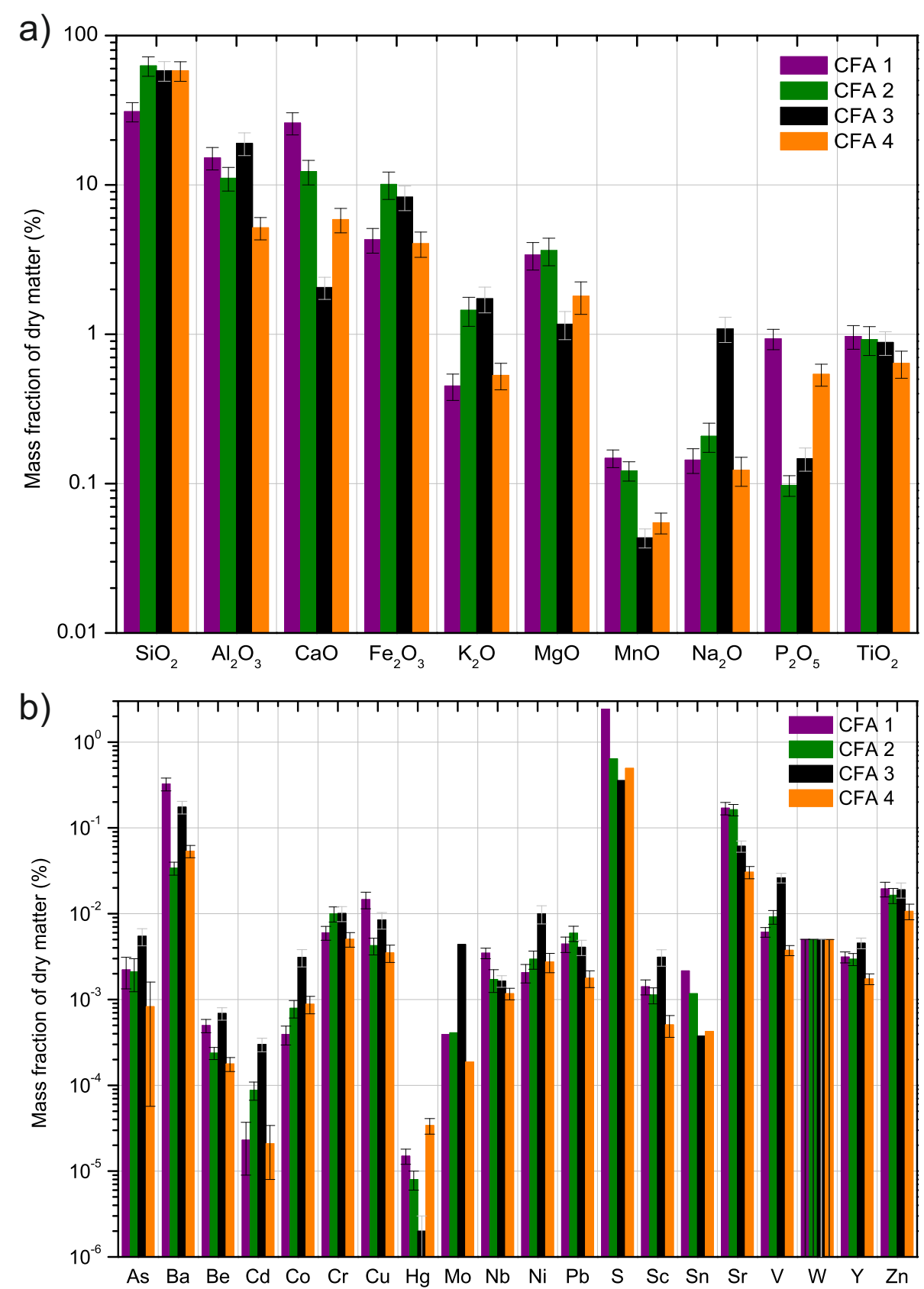

Figure S10. Mass fractions of a) major oxides (calculated from elemental mass fractions) and b) minor elements in CFA dry bulk material. 


\section{Size Distributions}

Mobility size distributions of CFA aerosol from wet-particle generation were measured with a Differential Mobility Particle Spectrometer (DMPS). An inversion routine (similar to Stratmann and Wiedensohler, 1996) was used to obtain size distributions (see Fig. S11). This was done to exclude the possibility that the investigated $300 \mathrm{~nm}$ particles consist of purely watersoluble material which would bias the LACIS measurements. Water-soluble particles would dissolve when being activated to cloud droplets and freezing would occur due to homogeneous nucleation only. In this case, $f_{\text {ice }}$ would be underestimated and a correction would be necessary.

The size distributions appear to be tri-modal. However, a bi-modal fit was applied, as only part of the third mode was captured. The fitting was performed to identify the size range of the different occurring modes. In contrast to earlier publications (Damle et al., 1982; Flagan and Seinfeld, 1988), where CFA size distributions were characterized as bi-modal, with the first submicron mode representing particles formed from the gas phase by nucleation/condensation and the second supermicron mode representing residual ash particles, Linak et al. (2002) describe a tri-modal size distribution with an additional mode enclosed between nucleation/condensation mode and residual ash mode. This "fine fragmentation" mode could be equal to mode 2 in the shown CFA size distributions. Mode 1 at smaller sizes originates from water-soluble substances in the suspension and conceals the nucleation/condensation mode.

In case of CFA2, CFA3, and CFA4, suspensions were prepared in the same way as for LACIS measurements, i.e., by suspending $0.5 \mathrm{wt} \%$ of CFA in water, $10 \mathrm{~min}$ of ultrasonification, and $24 \mathrm{~h}$ of stirring. For these samples, the ratio of concentrations of the two modes clearly shows that $300 \mathrm{~nm}$ particles almost exclusively consist of non-soluble material. Mode 1, i.e., water soluble material, does not contribute to the measured number concentrations of CFA2, CFA3, and CFA4 at 300 nm, meaning that no correction of $f_{\text {ice }}$ is needed.

In case of CFA1, a fresh suspension was prepared to minimize the occurrence of needles which would bias the size distribution. However, we suspect that needles already started forming during the size distribution measurement, which takes $\sim 15$ min. In fact, we observed a fresh CFA1 suspension droplet under an optical microscope and saw needle formation within $~ 10$ min. This would also explain, why the size distribution of CFA1 differs from those of the other samples: The mean of mode 1 is at $\sim 55 \mathrm{~nm}$ for CFA1, while it is between 30 and $40 \mathrm{~nm}$ for the other three CFA samples. Also, mode 1 is much broader for CFA1 in comparison to the others. This suggests that we measured the size distribution of an external mixture of needles and spheroidal CFA particles which cannot be separated from one another. Hence, no conclusion can be drawn about the occurrence of purely water-soluble particles at $300 \mathrm{~nm}$ for CFA1. 
a) CFA1

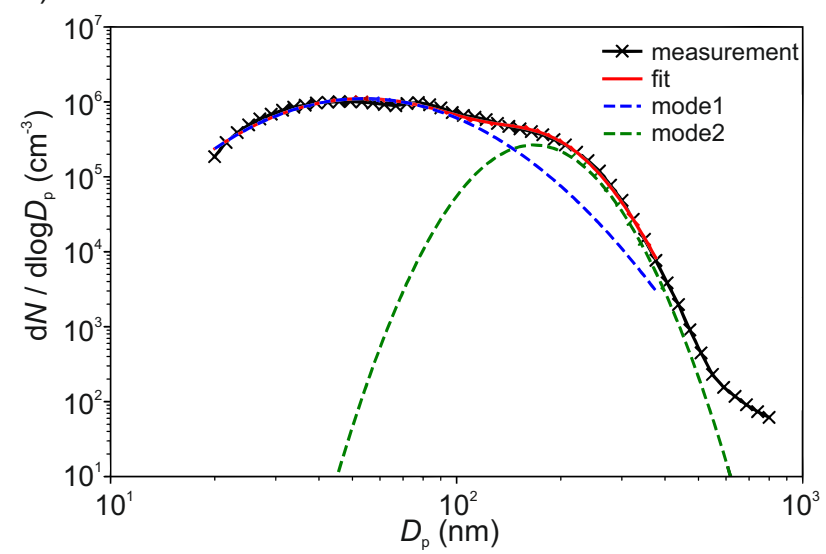

c) CFA3

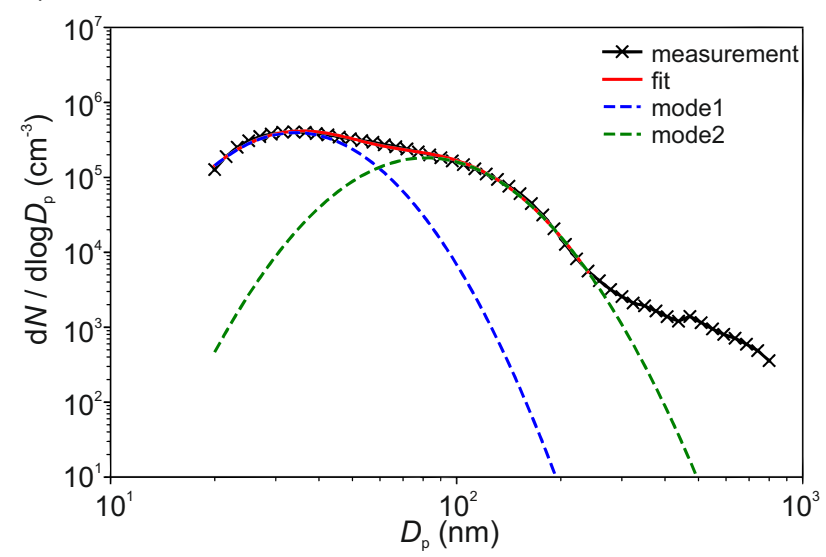

b) CFA2

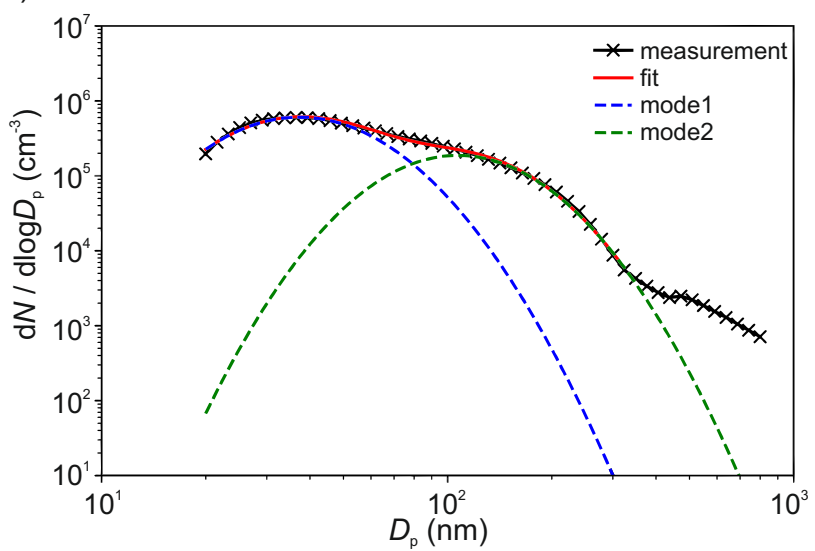

d) CFA4

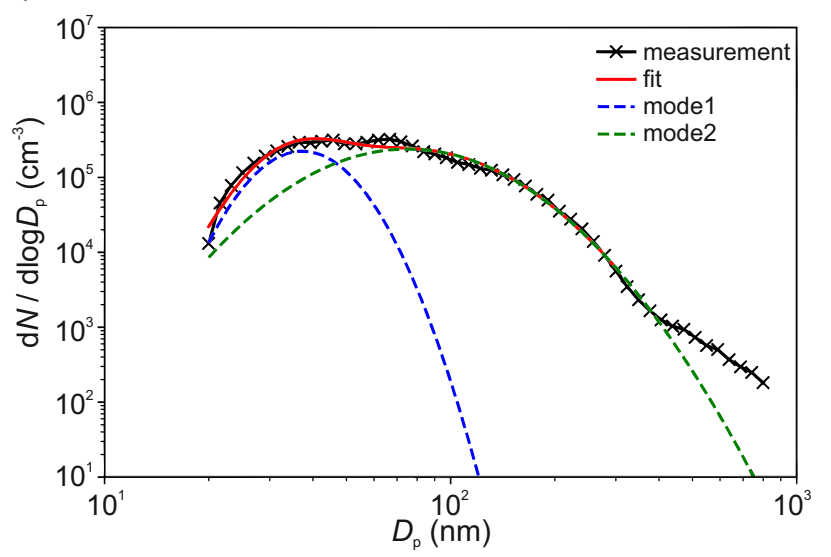

Figure S11. Size distributions from DMPS measurements with wet-generated CFA particles. a) Size distribution of particles generated from a freshly prepared CFA1 suspension. b), c), and d) Size distributions of aerosol generated from suspensions of CFA2, CFA3, and CFA4 that were ultrasonicated for $10 \mathrm{~min}$ and stirred for $24 \mathrm{~h}$. 

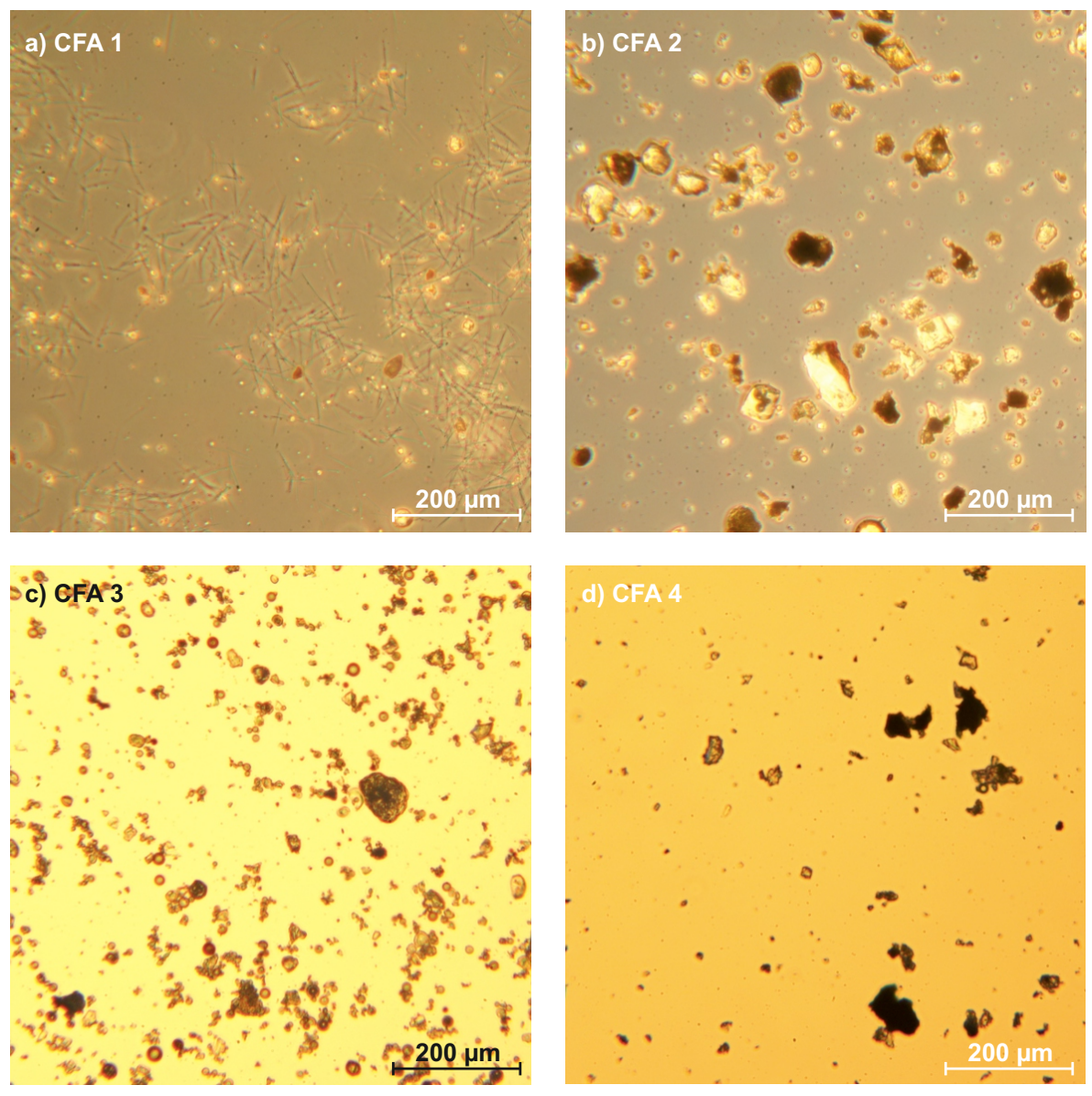

Figure S12. Optical microscope images of CFA suspension droplets. The suspensions were prepared in the same way as for LACIS measurements. a) CFA1, where needles are present in the aqueous environment. b), c), and d) CFA2, CFA3, and CFA4, where no needles were observed. 


\section{Multiple charge correction}

Multiple charge fractions were determined from ALABAMA size distribution measurements of the quasi-monodisperse aerosol (see Fig. S13). The black line represents the result of a least-squares fit assuming a four-modal normal distribution. The multiply charged fractions were determined by dividing the number of counts below the separate modes by the total number of counts.

5 The multiple charge correction of the measured $f_{\text {ice }}$ values was performed according to Hartmann et al. (2016) and BurkertKohn et al. (2017).

Note that multiply charged fractions differ substantially for the different samples and particle generation methods, and, in case of dry particle generation, also increase with duration of the experiment. On the one hand, this increase could be caused by a decreasing efficiency of the cyclone due to accumulated material within. On the other hand, there is a temporal shift in size distribution of particles in the reservoir of the aerosol generator. Hence, multiply charged fractions of dry-generated CFA were determined specifically for those points in time when LACIS measurements took place. Multiply charged fractions given in Table S2 are averaged values for a time frame starting 1 hour after particle generation was turned on and lasting 20 minutes, which is when most LACIS measurements took place. LACIS data acquired at an earlier point in time were corrected with the respective multiply charged fractions (not shown).

Table S2. Multiply charged fractions as determined from ALABAMA size distribution measurements.

\begin{tabular}{rrrrrr}
\hline $\boldsymbol{n}$ & 1 & 2 & 3 & 4 & 5 \\
$\boldsymbol{D}_{\mathbf{p}}(\mathbf{n m})$ & 300 & 507 & 706 & 902 & 1097 \\
\hline CFA 1 dry & 0.81 & 0.19 & - & - & \\
CFA 2 dry & 0.59 & 0.29 & 0.09 & 0.03 & \\
CFA 3 dry & 0.28 & 0.38 & 0.24 & 0.1 & \\
CFA 4 dry & 0.67 & 0.21 & 0.07 & 0.05 & \\
\hline CFA 1 wet & 0.59 & 0.33 & 0.05 & 0.03 & \\
CFA 2 wet & 0.58 & 0.36 & 0.04 & 0.02 & \\
CFA 3 wet & 0.34 & 0.40 & 0.09 & 0.09 & 0.08 \\
CFA 4 wet & 0.6 & 0.29 & 0.06 & 0.05 & \\
\hline
\end{tabular}




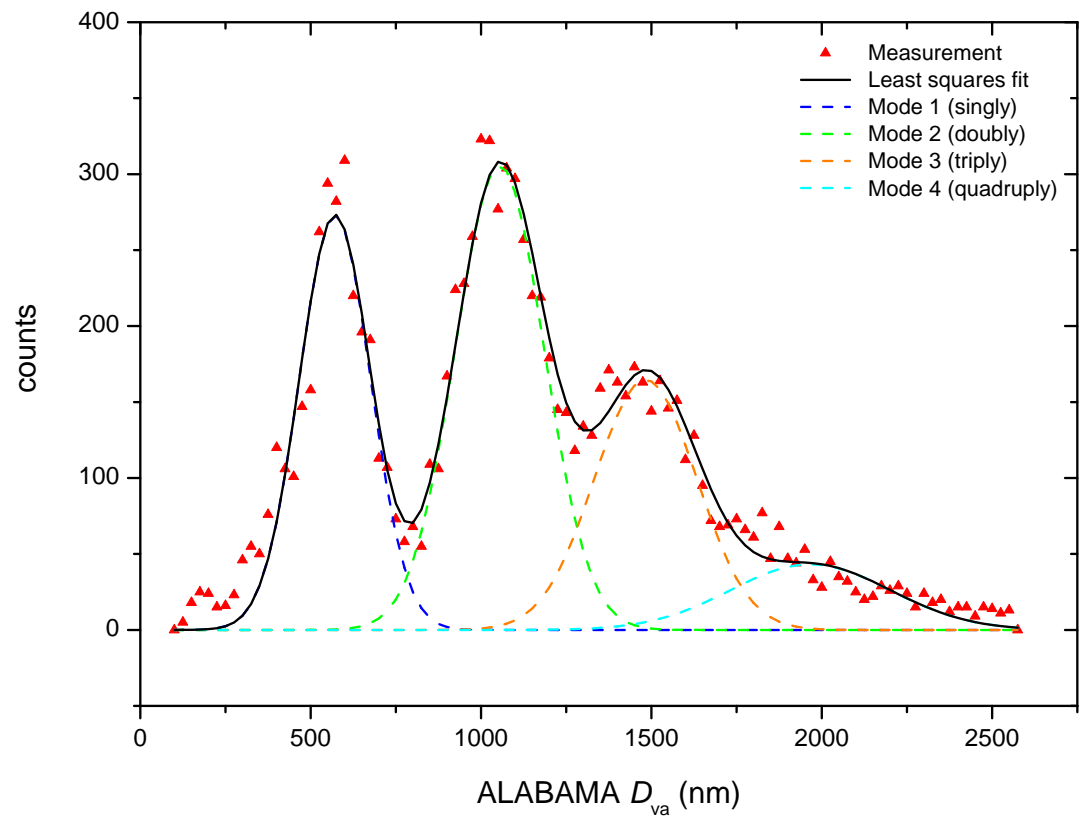

Figure S13. Average size distribution of dry-generated CFA3 particles measured with ALABAMA. $D_{\text {va }}$ is the vaccuum aerodynamic diameter. 


\section{BET specific surface area}

The specific surface area of the four CFA samples was determined by multi-point BET (Quantachrome Instruments, Odelzhausen, Germany) measurements using $\mathrm{N}_{2}$ gas. The results of the BET measurements are shown in Table S3. Measurements with CFA1, CFA2, and CFA3 only yielded reasonable results after long degassing, and the results are close to the limit of detection. The

5 uncertainties given in Table S3 are the standard deviation of at least three measurements. Independent measurements with bulk CFA at a different laboratory showed very similar results (CFA1: $1.7 \mathrm{~m}^{2} \mathrm{~g}^{-1}$, CFA2: $4 \mathrm{~m}^{2} \mathrm{~g}^{-1}$, CFA3: $1 \mathrm{~m}^{2} \mathrm{~g}^{-1}$, CFA4: 52 $\mathrm{m}^{2} \mathrm{~g}^{-1}$ ), indicating that the low values given in Table $\mathrm{S} 3$ are trustworthy. Determination of the pore volume fraction showed that CFA1, CFA2, and CFA3 are non-porous, CFA4 has low porosity.

Table S3. BET specific surface area of bulk (used for LINA $n_{\mathrm{s}}$ calculations) and fine CFA (used for WISDOM $n_{\mathrm{s}}$ calculations).

\begin{tabular}{cc}
\hline CFA sample & BET specific surface area $\left(\mathrm{m}^{2} \mathrm{~g}^{-1}\right)$ \\
\hline 1 bulk & $1.4 \pm 0.3$ \\
1 fine & $1.2 \pm 0.2$ \\
2 bulk & $5.9 \pm 0.6$ \\
3 bulk & $1.5 \pm 0.3$ \\
4 bulk & $49.4 \pm 0.7$ \\
\hline
\end{tabular}




\section{References}

Ahmaruzzaman, M.: A review on the utilization of fly ash, Progress in energy and combustion science, 36, 327-363, 2010.

ASTM: C618. Standard specification for coal fly ash and raw or calcined natural pozzolan for use in concrete, Tech. rep., American Society for Testing and Materials, West Conshohocken, PA, USA, 2015.

5 Block, C. and Dams, R.: Study of fly ash emission during combustion of coal, Environmental Science and Technology, Vol. 10, No. 10, pp. 1011-1017, 1976.

Burkert-Kohn, M., Wex, H., Welti, A., Hartmann, S., Grawe, S., Hellner, L., Herenz, P., Atkinson, J. D., Stratmann, F., and Kanji, Z. A.: Leipzig Ice Nucleation chamber Comparison (LINC): Inter-comparison of four online ice nucleation counters, Atmospheric Chemistry and Physics Discussions, 2017, 1-30, doi:10.5194/acp-2017-358, https://www.atmos-chem-phys-discuss.net/acp-2017-358/, 2017.

Canpolat, F., Yılmaz, K., Köse, M. M., Sümer, M., and Yurdusev, M. A.: Use of zeolite, coal bottom ash and fly ash as replacement materials in cement production, Cement and Concrete Research, 34, pp. 731-735, 2004.

Damle, A. S., Ensor, D. S., and Ranade, M. B.: Coal combustion mechanisms: A review, Aerosol Science and Technology, 1, pp. 119-133, 1982.

Davison, R. L., Natusch, D. F. S., Wallace, J. R., and Evans Jr., C. A.: Trace elements in fly ash: dependence of concentration on particle size, Environmental Science \& Technology, 8, 1974.

Enders, M.: The $\mathrm{CaO}$ distribution to mineral phases in a high calcium fly ash from Eastern Germany, Cement and Concrete Research, 26, 243-251, 1996.

Flagan, R. C. and Seinfeld, J. H.: Fundamentals of Air Pollution Engineering, chap. Particle formation in combustion, pp. 358-390, PrenticeHall, Inc., Englewood Cliffs, New Jersey, 1988.

Flanders, P. J.: Identifying fly ash at a distance from fossil fuel power stations, Environmental Science \& Technology, 33, 528-532, doi:10.1021/es980942s, 1999.

Gallavardin, S. J., Lohmann, U., and Cziczo, D. J.: Analysis and differentiation of mineral dust by single particle laser mass spectrometry, International Journal of Mass Spectrometry, 274, 56-63, 2008.

Garimella, S.: A vertically-integrated approach to climate science : From measurements and machine learning to models and policy, Ph.D. thesis, Massachusetts Institute of Technology, 2016.

Gladney, E. S., Small, J. A., Gordon, G. E., and Zoller, W. H.: Composition and size distribution of in-stack particulate material at a coal-fired power plant, Atmospheric Environment, Vol. 10, pp. 1071-1077, 1976.

Hartmann, S., Wex, H., Clauß, T., Augustin-Bauditz, S., Niedermeier, D., Rösch, M., and Stratmann, F.: Immersion freezing of kaolinite: Scaling with particle surface area, Journal of the Atmospheric Sciences, Vol. 73, pp. 263-278, 2016.

30 Herich, H., Tritscher, T., Wiacek, A., Gysel, M., Weingartner, E., Lohmann, U., Baltensperger, U., and Cziczo, D. J.: Water uptake of clay and desert dust aerosol particles at sub- and supersaturated water vapor conditions, Physical Chemistry Chemical Physics, 11, pp. 7804-7809, 2009.

Kaakinen, J. W., Jorden, R. M., Lawasani, M. H., and West, R. E.: Trace element behavior in coal-fired power plant, Environmental Science and Technology, Vol. 9, No. 9, pp. 862-869, 1975.

35 Liang, Z., He, X., and Ni, J.: Change of crystallinity and mineral composition of fly ash with mechanical and chemical activation for the improvement of phosphate uptake, Waste Management \& Research, 28, 901-907, 2010. 
Linak, W. P., Miller, C. A., Seames, W. S., Wendt, J. O. L., Ishinomori, T., Endo, Y., and Miyamae, S.: On trimodal particle size distributions in fly ash from pulverized-coal combustion, Proceedings of the Combustion Institute, 29, 441-447, 2002.

Matsunaga, T., Kim, J. K., Hardcastle, S., and Rohatgi, P. K.: Crystallinity and selected properties of fly ash particles, Materials Science and Engineering: A, 325, 333-343, doi:10.1016/S0921-5093(01)01466-6, 2002.

5 McCarthy, G. J., Swanson, K. D., Keller, L. P., and Blatter, W. C.: Mineralogy of western fly ash, Cement and Concrete Research, 14, 471-478, 1984.

Nathan, Y., Dvorachek, M., Pelly, I., and Mimran, U.: Characterization of coal fly ash from Israel, Fuel, 78, $205-213,1999$.

Nyambura, M. G., Mugera, G. W., Felicia, P. L., and Gathura, N. P.: Carbonation of brine impacted fractionated coal fly ash: Implications for $\mathrm{CO}_{2}$ sequestration, Journal of Environmental Management, 92, 655-664, 2011.

10 Querol, X., Alastuey, A., Lopez-Soler, A., Mantilla, E., and Plana, F.: Mineral composition of atmospheric particulates around a large coalfired power station, Atmospheric Environment, Vol. 30, No. 21, pp. 3557-3572, 1996.

Ramsden, A. R. and Shibaoka, M.: Characterization and analysis of individual fly-ash particles from coal-fired power stations by a combination of optical microscopy, electron microscopy and quantitative electron microprobe analysis, Atmospheric Environment, Vol. 16, No. 9, pp. 2191-2206, 1982.

Seames, W. S.: An initial study of the fine fragmentation fly ash particle mode generated during pulverized coal combustion, Fuel Processing Technology, 81, 109-125, 2003.

Shoumkova, A., Tsacheva, T., Stoyanova, V., Grancharov, I., Shumkov, S., and Marinov, M.: Physico-chemical and morphological properties of coal fly ash from Varna power plant, Bulgaria, in: Proceedings of the Third International Conference on Ecological Chemistry, pp. $560-570,2005$.

Steenari, B. M., Schelander, S., and Lindqvist, O.: Chemical and leaching characteristics of ash from combustion of coal, peat and wood in a 12 MW CFB - A comparative study, Fuel, 78, pp. 249-258, 1999.

Stratmann, F. and Wiedensohler, A.: A new data inversion algorithm for DMPS-measurements, Journal of Aerosol Science, Vol. 27, Suppl. 1, pp. 339-340, 1996.

Tan, P. V., Fila, M. S., Evans, G. J., and Jervis, R. E.: Aerosol laser ablation mass spectrometry of suspended powders from PM sources and its implications to receptor modeling, Journal of the Air \& Waste Management Association, 52, 27-40, 2002.

Umo, N. S., Murray, B. J., Baeza-Romero, M. T., Jones, J. M., Lea-Langton, A. R., Malkin, T. L., O’Sullivan, D., Neve, L., Plane, J. M. C., and Williams, A.: Ice nucleation by combustion ash particles at conditions relevant to mixed-phase clouds, Atmospheric Chemistry and Physics, 15, pp. 5195-5210, 2015.

Ward, C. R. and French, D.: Determination of glass content and estimation of glass composition in fly ash using quantitative X-ray diffractometry, Fuel, 85, 2268-2277, doi:10.1016/j.fuel.2005.12.026, 2006.

Zhang, L., Ninomiya, Y., and Yamashita, T.: Formation of submicron particulate matter (PM1) during coal combustion and influence of reaction temperature, Fuel, 85, 1446-1457, 2006.

Zhang, X., Wu, G., Yao, T., Zhang, C., and Yue, Y.: Characterization of individual fly ash particles in surface snow at Urumqi Glacier No. 1, Eastern Tianshan, Chinese Science Bulletin, Vol. 56, No. 32, pp. 3464-3473, 2011. 